\title{
Urban Grassroots Movements in Central and Eastern Europe
}

Kerstin Jacobsson (red.)

Farnham: Ashgate 2015

309 sider. ISBS 9781472434463

Anmeldt av Katalin Miklóssy [PhD, seniorforsker ved Alekxanderinstituttet, Helsingfors universitet, katalin.miklossy@helsinki.fi]

Jeg er glad for å kunne presentere denne utmerkede boken som er basert på papers presentert på en internasjonal konferanse holdt på Södertörn Högskola i Sverige i 2013. Boken fyller et kunnskapshull hva gjelder forskning på urbane bevegelser i Sentral- og Øst-Europa og peker ut en ny forskningsretning ved å forene fagfeltet urbane studier med teori om sosiale bevegelser. Betydningen av områdespesifikke faktorer er mye debattert innen begge disse feltene. Mange hevder at man ved å referere til en post-kommunistisk sfære bedriver «othering» basert på en antagelse om Øst-Europas underlegenhet i forhold til Vest-Europa. På grunn av landenes felles erfaring med dramatiske sosiale transformasjoner i løpet av relativt kort tid, argumenterer imidlertid denne samlingen for at denne regionen faktisk er en distinkt geografisk enhet. Hurtige privatiseringsprosesser i det urbane miljøet innebar at ansvaret for boligpolitikk og sosiale tjenester ble overført fra staten til lokale myndigheter som ikke var tilstrekkelig forberedt for oppgaven. Dette skapte grobunn for urbane protester, særlig på grasrotnivå.

Boken tilbyr også et forfriskende alternativ til den dominerende NGO-orienterte forståelsen av hvordan et sivilsamfunn skal og kan se ut. Den utfordrer i så måte den konvensjonelle antagelsen om at post-sovjetiske land har svake sivilsamfunn. Som noen av artiklene peker på, så mangler NGO-er i disse samfunnene tillit fordi de ses på som korrupte og drevet av bakenforliggende interesser. Samlingens kanskje mest interessante bidrag er derfor en bedre forståelse av hva grasrotaktivisme kan fortelle oss om sivilsamfunnet.

Boken er redigert på en svært god måte. En informativ introduksjon og tankevekkende konklusjon bidrar til det som i seg selv er en kompakt samling temaer og analyser ført i ulike narrative stiler. Artiklene anvender ulike teoretiske tilnærminger til studiet av sosiale bevegelser og utdyper disse gjennom varierte casestudier. Boken vil derfor passe godt som lærebok i introduksjonsemner innen sosiale bevegelser og aktivisme i det post-sovjetiske området. Forfatterne er sosiologer, sosialantropologer og kulturhistorikere og studerer russiske, ukrainske, litauiske, polske, slovakiske, rumenske, kroatiske og serbiske bevegelser. 
Det urbane rommet ses gjennomgående som et sted der identiteter, mål, meninger og strategier for kollektiv handling artikuleres. Kerstin Jacobsson tilbyr et prisme som kan anvendes for å behandle bokens vide spekter av emner. På tross av å være ulike, har emnene likevel en rekke fellesnevnere. Casene i samlingen tar alle for seg grasrotaktivismens ulike formål og roller: forhandling av urban identitet og mening, dannelse av nye former for samfunnsborgerskap, etablering av allianser og strategiske samarbeid mellom ulike sosiale bevegelser og forsøk på å oppnå innflytelse gjennom urban styring og kontroll. I boken finner vi studier av sosiale bevegelser som forsøker å endre det urbane rommet i seg selv, samt tilfeller hvor det urbane rommet fungerer som en plattform for å nå andre sosiale formål. Alle bevegelsene som diskuteres er forankret i lokale opplevelser av smertefulle demokratiseringsprosesser og de angir ulike måter å håndtere disse på i sitt daglige virke.

Sosiale bevegelser som søker å utvide, endre og/eller ta over det urbane området diskuteres i artikler som tar for seg bevaring av kulturarv i Bucuresti (Florea), «retten til byen»-aktivisme i Serbia og Kroatia (Bilić og Stubbs) og protester mot byplanlegging i St. Petersburg (Tykanova og Bilić). Beatriz Lindqvist poengterer viktigheten av å tillate ideologisk fleksibilitet og mangeartede identiteter, i sitt studie av antikapitalistiske bevegelsers deltagelse $\mathrm{i}$ arbeid mot privatisering av offentlig rom $\mathrm{i}$ Vilnius. Tilfellet med sykkelaktivisme, som presenteres av Sabrina Kopf, er en fascinerende analyse av ulike aspekter relatert til anskaffelse av mer urbane områder i Beograd. Kopf viser at syklistenes visjon om modernitet og «den moderne byen» er rotfestet i en forståelse av grasrotorienterte sivile handlinger som det som utgjør medborgerskap. Denne typen ekte samfunnsborgerskap (gradani) befinner seg imidlertid $i$ antipolitikkens domene fordi bevegelsen fjerner seg fra mer organiserte typer aktivisme, det vil si fra NGO-ene som de anser som del av det korrupte og ineffektive politiske etablissementet.

Boken inkluderer studier av grasrotaktivisme hvor den urbane settingen gir rom for handling med sosialt og/eller politisk formål. Dette er eksempelvis tilfelle i Karine Cléments artikkel. Den viser hvordan generell misnøye med forverrede sosioøkonomiske forhold i Kaliningrad først blir utrykt gjennom parallelle grasrotkampanjer. Samarbeidet mellom de ulike bevegelsene utvikler seg gradvis til massedemonstrasjoner som til slutt oppnår å avsette den regionale guvernøren. På samme måte er Dominika V. Polanskas studie fra Polen et illustrerende eksempel på hvordan tilgang til den lokale beslutningstakningssfæren kan oppnås gjennom å bygge allianser mellom leietakerforeninger og husokkupantbevegelser og videre inngå strategisk samarbeid med høyt utdannede grupper.

En av de mest interessante studiene er Olena Leipniks artikkel om aktivisme blant eldre i Ukraina. Litteraturen om sosiale bevegelser ser ofte på unge som den progressive kraften, og eldres aktivisme er derfor et oversett fenomen. Leipnik viser hvordan eldre ikke er de passive mottagerne av sosiale goder som de ofte blir framstilt som, men tvert imot involverer seg i diverse sosiale bevegelser og dermed fungerer som aktivister uten å nødvendigvis være bevisst dette selv. I den opphetede situasjonen som har preget Ukraina har det likevel vært forsøk på å begrense de eldres politiske 


\section{0 | KATALIN MIKLÓSSY}

rettigheter fordi man ikke stoler på dem som en demokratiserende kraft i og med at de er generasjonen som ses på som ansvarlig for den sovjetiske fortiden.

$\mathrm{Vi}$ ser stadig flere grasrotbevegelser i øst-europeiske urbane rom som bør bli gjenstand for forskning. Det karakteristiske ved disse bevegelsene er at de er sammenfiltringer av globale og lokale fenomen i en post-kommunistisk kontekst. Å studere dem krever derfor en bred tilnærming som evner å krysse forskningstradisjoners grenser på samme måte som i denne boken.

Oversatt av Malin Østevik 